\title{
Phellinus species on Betula. Mating tests, RFLP analysis of enzymatically amplified rDNA, and relations to Phellinus alni
}

\author{
MICHAEL FISCHER and MANFRED BINDER
}

FISCHER, M. \& BINDER, M. 1994: Phellinus species on Betula Mating tests, RFLP analysis of enzymatically amplified rDNA, and relations to Phellinus alni. - Karstenia 35:67-84. Helsinki. ISSN 0453-3402

Mainly based on collections from Fennoscandia, Estonia, and Central Europe, four species of the genus Phellinus Quél. (Hymenochaetaceae), all belonging to the $P$. igniarius (L.:Fr.) Quél. group, are shown to occur on Betula L. These species are $P$. nigricans (Fr.) P.Karsten, P. cinereus (Niemelä) Fischer, P. laevigatus (Fr. ex P.Karsten) Bourd. \& Galz., and $P$. lundellii Niemelä. The occurrence of $P$. igniarius and $P$. alni (Bond.) Parm. on Betula remains in doubt. P. alni, P. nigricans, P. cinereus, P. laevigatus, and $P$. lundellii were characterized by pairing tests of single spore mycelia and RFLP (restriction fragment length polymorphism) data of enzymatically amplified ribosomal DNA. A unique RFLP phenotype was assignable to each species except $P$. nigricans, which was identical with $P$. alni. Distribution of the taxa is throughout the area under study; however, $P$. nigricans seems to be limited to Fennoscandia. Two stocks from North America proved to represent $P$. cinereus. Pairing relationships between $P$. nigricans, $P$. cinereus, and $P$. alni were examined in detail and were found to differ according to the geographic origin of the stocks. $P$. nigricans was positive in numerous pairings with $P$. alni from Fennoscandia, Estonia, and Central Europe. In addition, it is positive with $P$. cinereus from Fennoscandia, but negative with $P$. cinereus from Central Europe, Estonia, and the United States. P. laevigatus and P. lundellii were intersterile with all other taxa.

Key words: Betula, pairing tests, PCR, Phellinus, RFLP, speciation

Michael Fischer, Institut für Botanik, Universität Regensburg, D-93040 Regensburg, Germany; Manfred Binder, Institut für Botanik, Universität Regensburg, D-93040 Regensburg, Germany

\section{Introduction}

According to the literature, in Europe a considerable number of taxa of the genus Phellinus Quél. are found on Betula L. All these taxa are members of the P. igniarius (L.:Fr.) Quél. group. Species concepts within this group are primarily based on macroscopical and microscopical features, culture characteristics and host plants (Bondartsev 1953; Kreisel 1961, 1987; Jahn 1962, 1963, 1967, 1977, 1979; Donk 1971, 1974; Niemelä 1972, 1974, 1975, 1977; Domanski et al. 1973; Parmasto 1976, 1985, 1993; Fischer 1987, 1995).
Substrate specificity is pronounced for some taxa of the group. P. tuberculosus (Baumg.) Niemelä is almost exclusively found on species of Prunus L. (Bondartsev 1953; Kreisel 1961; Jahn 1963; Niemelä 1977; Breitenbach \& Kränzlin 1986). P. tremulae (Bond.) Bond. \& Borisov (Bondartsev 1953; Jahn 1962; Domanski et al. 1973; Niemelä 1974) and $P$. populicola Niemelä (Niemelä 1975; Jahn 1979; Kreisel 1987) are limited to Populus L. In Central Europe, the type species of the group, $P$. igniarius, so far has been demonstrated only for species of Salix L. (Fischer 1995). Possibly it also grows on Populus (Eriksson 
1958; Kreisel 1961; Jahn 1963; Domanski et al. 1973; Niemelä 1975; Benkert 1977; Niemelä \& Kotiranta 1982), but at least some of these findings represent $P$. populicola instead.

For some of the Phellinus taxa occurring on Betula this tree represents the main host; for others it is a host of secondary importance.

\section{Phellinus igniarius (L.: Fr.) Quél.}

The host preference of this taxon evidently varies with the geographic region. As mentioned above, in Central Europe it seems limited to species of Salix, though this is in contrast to reports by Kreisel (1961, 1987), Jahn (1963, 1979), Plank (1978), Kotlaba (1984) and Breitenbach and Kränzlin (1986), who suggest that it occurs on a wide variety of deciduous trees including Betula. Most likely, the majority of these reports properly refer to the closely related species $P$. alni (Bond.) Parm. In Fennoscandia, Betula is cited as the main host of $P$. igniarius (Eriksson 1958; Niemelä 1975; Niemelä \& Kotiranta 1982; Erkkilä \& Niemelä 1986; Renvall et al. 1991); besides, the taxon is found on Salix and numerous other trees. As well, in the eastern part of Europe and the territory of the former USSR Betula is reported as common host (Bondartsev 1953; Domanski et al. 1973). As pointed out by Niemelä (pers. comm.), however, in Finland most collections of $P$. igniarius from Betula in fact represent $P$. cinereus (Niemelä) Fischer (see below). Betula is not included as host of $P$. igniarius in the "Distribution maps of Estonian fungi" (Parmasto 1993). Nothing definite can be said about the collections of Eastern Europe, since for this part of its range the species concept of $P$. igniarius has not yet been fully clarified.

\section{Phellinus alni (Bond.) Parm.}

As with $P$. igniarius, occurrence of this taxon on Betula is questionable. Little is said in the literature about the host preferences of $P$. alni. Alnus Mill. is cited as substrate by Bondartsev (1912, 1953), who was the first to mention the taxon (first as Fomes igniarius f. alni Bond. and later as P. igniarius f. alni Bond.). P. igniarius var. alni was proposed as one of four varieties of $P$. igniarius by Niemelä (1975); occurrence is typically given as on Alnus glutinosa, but also on most of the other tree hosts of $P$. igniarius, possibly including Betula. P. alni was raised to specific rank in Parmasto's study on Yakutian fungi (Parmasto 1976), where it is reported as occurring on Betula. Betula is not mentioned as host of P. alni in Estonia (Parmasto 1993); however, numerous collections from Betula morphologically are very close to $P$. alni (Parmasto, pers. comm.).

\section{Phellinus nigricans (Fr.) P.Karsten}

Although the concept of this species is still unsettled (Donk 1971, 1974; Fischer 1995), it is usually recognized in the literature. The designations are variable, i.e. $P$. igniarius $\mathrm{f}$. nigricans Bondartsev (Bondartsev 1953), $P$. trivialis $\mathrm{f}$. betularum Jahn (Jahn 1963), and $P$. nigricans (Domanski et al. 1973; Niemelä 1975; Niemelä \& Kotiranta 1982; Jülich 1984; Breitenbach \& Kränzlin 1986; Parmasto 1993). In all cases Betula is given as the main host, preferentially dead or severely wounded stems. This is in contrast to $P$. igniarius and $P$. alni, both of which occur as parasites. The distribution of $P$. nigricans is boreal (Niemelä 1975; Jahn 1979), and it also is reported from Estonia (Parmasto 1993, pers. comm.). As noted by Niemelä and Kotiranta (1982), reports of $P$. nigricans from Central Europe and further south are due to a misunderstanding of the species concept. Since P. trivialis (Bres.) Kreisel is included in the species concept of $P$. nigricans by Domanski et al. (1973), the same may be true for the Polish collections of $P$. nigricans. The species is considered to exist in Switzerland; findings, mostly on Betula, are rare however (Breitenbach \& Kränzlin 1986).

\section{Phellinus cinereus (Niemelä) Fischer}

Mainly on the basis of specimens from Central Europe, this taxon was just recently raised to specific level (Fischer 1995). Originally designated as $P$. igniarius var. cinereus Niemelä (Niemelä 1975), it has also been mentioned by Jahn and Jahn (1986), Parmasto (1993), and Luschka (1994). P. cinereus seems to be closely associated with Betula, occurrence on dead Alnus incana is reported by Niemelä (1975). Possibly it also grows on Acer L., Fraxinus L., and Ulmus L. (Parmasto, 1993). Ecologically $P$. cinereus is 
very similar to $P$. nigricans, but differs in that it sometimes also occurs on standing, living trees. In Germany, one of us (M.F.) found P. cinereus exclusively in moist sites of dense forests, saprophytically on dead, standing birch.

\section{P. laevigatus (Fr. ex P.Karsten) Bourd. \& Galz.}

This is another species mostly growing on Betula. Bourdot \& Galzin (1927) and Bondartsev (1953) cite Rhamnus L. as host, but probably all their findings refer to P. rhamni (Bond.) Jahn (Jahn 1967). Distribution of $P$. laevigatus is scattered, but in suitable sites the species seems to occur in most parts of Europe (Bondartsev 1953; Eriksson 1958; Kreisel 1961, 1987; Jahn 1967; Domanski 1972; Niemelä 1972; Plank 1978; Niemelä \& Kotiranta 1982; Kotlaba 1984; Breitenbach \& Kränzlin 1986; Parmasto 1993; Luschka 1994). It prefers dead, fallen stems of birch in dense forests, where large, resupinate fruiting bodies often develop on the underside of the fallen tree. Occasionally it is found on Alnus (Niemelä 1972; Niemelä \& Kotiranta 1982; Kotlaba 1984; Breitenbach \& Kränzlin 1986). On birch, it often grows side by side with Piptoporus betulinus (Bull.:Fr.) P.Karsten and Fomes fomentarius (L.) Fr. (Jahn 1967).

\section{P. lundellii Niemelä}

This taxon is readily found in suitable places in Northern Europe (Niemelä 1975; Niemelä \& Kotiranta 1982). It is rare in Estonia (Parmasto 1993) and there is only one report from Poland (Domanski et al. 1973). Occurrence in Germany was reported only recently (Jahn 1977). Yet, also in Central Europe the species seems to occur regularly in low mountains and bogs or marshes (Kotlaba 1984; Breitenbach \& Kränzlin 1986; Luschka 1994). The ecology of $P$. lundellii is very similar to that of $P$. laevigatus in that fruiting bodies mostly are developed on dead trunks of birch. Sometimes P. lundellii also occurs on Alnus and other deciduous trees. Compared with $P$. laevigatus, $P$. lundellii more likely is to be found in remote areas, and its fruiting bodies usually appear at a later stage. (Niemelä 1972; Niemelä \& Kotiranta 1982).

Betula is the main substrate for four of the species listed above: $P$. nigricans, $P$. cinereus, $P$. laevigatus and $P$. lundellii. Because no unequivocal data exist for $P$. igniarius and $P$. alni, occurrence of these taxa on Betula in Europe remains doubtful.

Macroscopical and microscopical characters will usually allow a reliable identification of specimens in $P$. laevigatus and $P$. lundellii, but identification is much more difficult in $P$. igniarius, $P$. alni, $P$. nigricans, and $P$. cinereus. A species concept that is applicable in one region may fail in another. Characters that are less dependent on environmental factors - restriction data of enzymatically amplified ribosomal DNA as well as pairing tests of single spore mycelia and identification of the pattern of sexuality - were introduced recently as an additional aid in identifying specimens (Fischer 1995). Mainly on the basis of material from Central Europe, results were as follows: P. igniarius, P. alni, P. nigricans and $P$. cinereus are unifactorial. Pairing tests demonstrated a full intersterility between $P$. igniarius, $P$. alni and $P$. cinereus. P. nigricans (two stocks from Fennoscandia) was positive in numerous pairings with $P$. alni (mostly from Central Europe), and in one case also positive with $P$. cinereus (from Central Europe). Because of limited material, a full evaluation of the interrelations between these taxa was not possible.

It was the main purpose of this study to include additional stocks from outside of Central Europe. Specimens from Betula designated as P. igniarius s. str. were not available and therefore this species was not included. Special attention was paid to the relationships between $P$. alni, $P$. nigricans, and $P$. cinereus. No unambiguous material of $P$. alni on Betula was available, and stocks from different substrata were included instead. Numerous collections from Fennoscandia were provided by Dr. T. Niemelä, and stock cultures from Estonia and Russia were provided by Dr. E. Parmasto. For the first time the mode of reproduction as well as RFLP data are presented for $P$. laevigatus and $P$. lundellii. As was shown in the P. pini (Brot.:Fr.) Ames group, North American taxa cannot be related to known European species (Fischer 1994). For this reason, two North American collections from Betula were additionally tested in this study.

\section{Material and methods}

The collections used are listed in Table 1. 
Table 1. Phellinus on Betula: Field data of collections studied

\begin{tabular}{|c|c|c|c|c|}
\hline $\begin{array}{l}\text { Stock } \\
\text { number }\end{array}$ & Testers & $\begin{array}{l}\text { Date } \\
\text { collected }\end{array}$ & Location & Host \\
\hline $\begin{array}{l}\text { Phellinus sp.: } \\
76-18^{\mathrm{a}}\end{array}$ & & 25-VI-1976 & Estonia & Betula pendula Roth \\
\hline $\begin{array}{l}\text { P. alni: }{ }^{\mathrm{b}} \\
\text { TN 3214a } \\
85-87^{\mathrm{a}} \\
87-1028 \\
90-822 \\
\text { TN 5750 b } \\
71-9^{\mathrm{a}}\end{array}$ & $\begin{array}{l}2,6,7,8 \\
1,4,5,7 \\
1,2,3,5 \\
1,2,3,8 \\
1,2,3,4\end{array}$ & $\begin{array}{l}17-V I-1985 \\
7-V I I I-1985 \\
28-X-1987 \\
22-V I I I-1990 \\
24-I V-1994 \\
10-V-1971\end{array}$ & $\begin{array}{l}\text { Finland } \\
\text { Estonia } \\
\text { Germany } \\
\text { Germany } \\
\text { Finland } \\
\text { Estonia }\end{array}$ & $\begin{array}{l}\text { Alnus incana (L.) Moench } \\
\text { Alnus incana } \\
\text { Malus domestica Borkh. } \\
\text { Sorbus aucuparia L. } \\
\text { Alnus glutinosa (L.)Gaertn. } \\
\text { Alnus incana }\end{array}$ \\
\hline $\begin{array}{l}\text { P. nigricans: } \\
\text { TN } 3301^{\mathrm{b}} \\
\text { TN } 4405^{\mathrm{b}}\end{array}$ & $\begin{array}{l}1,2,8,11 \\
1,2,3,5\end{array}$ & $\begin{array}{l}5-X-1985 \\
24-V I-1987\end{array}$ & $\begin{array}{l}\text { Finland } \\
\text { Finland }\end{array}$ & $\begin{array}{l}\text { Betula } \\
\text { Betula pubescens Ehrh. }\end{array}$ \\
\hline $\begin{array}{l}\text { P. cinereus: } \\
85-917 \mathrm{a} \\
85-917 \mathrm{~b} \\
85-917 \mathrm{c} \\
\text { TN } 3308^{\mathrm{b}} \\
86-9 \mathrm{a} \\
86-9 \mathrm{~b} \\
86-9 \mathrm{c} \\
89-822 \mathrm{a}^{\mathrm{c}} \\
89-826^{\mathrm{c}} \\
89-828 \mathrm{~b} \\
90-826_{\mathrm{a}}^{\mathrm{c}} \\
90-826 \mathrm{~b} \\
92-926 \mathrm{~b} \\
92-927 \\
\text { TN } 5745^{\mathrm{b}} \\
\text { TN } 5747^{\mathrm{b}} \\
\text { TN } 5748^{\mathrm{b}} \\
\text { TN } 5756^{\mathrm{b}} \\
\text { TN } 5759^{\mathrm{b}} \\
70-4{ }^{\mathrm{a}} \\
71-15^{\mathrm{a}} \\
71-22^{\mathrm{a}}\end{array}$ & $\begin{array}{l}1,3,4,5 \\
1,2,3,4 \\
1,2,5,8 \\
1,2,3,5 \\
1,2,4,6 \\
1,4,5,6 \\
1,3,5,6 \\
1,2,3,4 \\
2,3,4,5 \\
1,3,4,5 \\
1,2,3,4 \\
1,2,5,6 \\
1,3,4,5 \\
1,2,3,4 \\
1,4,6,7 \\
1,2,3,4 \\
1,4,5,6\end{array}$ & $\begin{array}{l}17-I X-1985 \\
17-I X-1985 \\
17-I X-1985 \\
5-X-1985 \\
\text { IX-1986 } \\
\text { IX-1986 } \\
\text { IX-1986 } \\
22-V I I I-1989 \\
26-V I I I-1989 \\
28-V I I I-1989 \\
26-V I I I-1990 \\
26-V I I I-1990 \\
26-I X-1992 \\
27-I X-1992 \\
24-I V-1994 \\
24-I V-1994 \\
24-I V-1994 \\
31-V-1994 \\
8-V I-1994 \\
19-X I-1970 \\
17-V-1971 \\
20-V I I I-1971\end{array}$ & $\begin{array}{l}\text { Germany } \\
\text { Germany } \\
\text { Germany } \\
\text { Finland } \\
\text { Germany } \\
\text { Germany } \\
\text { Germany } \\
\text { Estonia } \\
\text { Estonia } \\
\text { Estonia } \\
\text { Germany } \\
\text { Germany } \\
\text { USA/Michigan } \\
\text { USA/Michigan } \\
\text { Finland } \\
\text { Finland } \\
\text { Finland } \\
\text { Finland } \\
\text { Finland } \\
\text { Estonia } \\
\text { Estonia } \\
\text { Russia } \\
\text { Vassiliev }\end{array}$ & $\begin{array}{l}\text { Betula pubescens } \\
\text { Betula pubescens } \\
\text { Betula pubescens } \\
\text { Betula } \\
\text { Betula pubescens } \\
\text { Betula pubescens } \\
\text { Betula pubescens } \\
\text { Betula } \\
\text { Tilia cordata L. } \\
\text { Betula } \\
\text { Betula pubescens } \\
\text { Betula pubescens } \\
\text { Betula papyrifera Marsh. } \\
\text { Betula papyrifera } \\
\text { Betula pubescens Ehrh. } \\
\text { Betula } \\
\text { Betula } \\
\text { Betula pubescens } \\
\text { Betula pubescens } \\
\text { Betula pendula } \\
\text { Betula pendula } \\
\text { Betula paraermanii }\end{array}$ \\
\hline $\begin{array}{l}\text { P. laevigatus: } \\
83-912 \\
\text { TN } 3260_{\mathrm{b}}^{\mathrm{b}} \\
\text { TN } 5769^{\mathrm{b}}\end{array}$ & $\begin{array}{l}1,2,3 \\
1,2,3,5 \\
2,3,4,5\end{array}$ & $\begin{array}{l}\text { 12-IX-1983 } \\
\text { 3-IX-1985 } \\
5-V I I-1994\end{array}$ & $\begin{array}{l}\text { Germany } \\
\text { Finland } \\
\text { Finland }\end{array}$ & $\begin{array}{l}\text { Betula pendula } \\
\text { Betula pubescens } \\
\text { Betula }\end{array}$ \\
\hline $\begin{array}{l}\text { P. lundelfii: } \\
\text { TN } 3259{ }^{\mathrm{b}} \\
86-1125^{\mathrm{d}} \\
89-119^{\mathrm{d}} \\
\text { TN } 5760^{\mathrm{b}}\end{array}$ & $\begin{array}{l}1,6,7,8 \\
1,3,4,5\end{array}$ & $\begin{array}{l}\text { 3-IX-1985 } \\
\text { 25-XI-1986 } \\
\text { 9-XI-1989 } \\
\text { 8-VI-1994 }\end{array}$ & $\begin{array}{l}\text { Finland } \\
\text { Germany } \\
\text { Germany } \\
\text { Finland }\end{array}$ & $\begin{array}{l}\text { Betula pubescens } \\
\text { Betula pubescens } \\
\text { Betula } \\
\text { Alnus incana }\end{array}$ \\
\hline
\end{tabular}

. nigr
TN 330 4405
. cine
$85-917$
$85-917$
$85-917$
TN 3308
$86-9 a$
$86-9 b$
$86-9 c$
$89-822 a$
$89-826$
$89-828$
$90-826$
$90-826 b$
$92-926 b$
$92-927$
TN 5745
TN 5747
TN 5748
TN 5756
TN 5759
$70-4{ }^{a}$
$71-15^{a}$
$1-22^{a}$

${ }_{\mathrm{b}}^{\mathrm{a}}$ provided by Erast Parmasto (TAA)

provided by Tuomo Niemel $(\mathrm{H})$

${ }_{\mathrm{d}}^{\mathrm{c}}$ provided by Andreas Bresinsky (REG)

provided by Norbert Luschka (REG) 


\section{Terms}

Stock refers to a fruiting body with specific mating type factors. Collection is synonymous with stock. A collection may consist of one to several fruiting bodies. Line of demarcation refers to a dark pigmented line in the medium between two mycelia that exhibit antagonistic behaviour (Adams \& Roth, 1967). Single spore mycelium is synonymous with isolate and refers to a mycelium developing from a single basidiospore. Secondary mycelium is a mycelium developing when two compatible single spore mycelia are paired. Such a mycelium can be subcultured as a stable heterokaryon.

\section{Cultural conditions}

All cultures were grown on malt agar (2\% agar, $2 \%$ malt extract, $0.05 \%$ yeast extract) at $23^{\circ} \mathrm{C}$ and $65 \%$ humidity in the dark. The $\mathrm{pH}$ was usually adjusted to about 5.0-5.5 with sodium citrate buffer $(0.05 \mathrm{M})$.

\section{Isolation of single spores}

A section of the hymenium was attached to the inside of a petri dish lid. Discharged spores were dispersed with Ringer's solution (NaCl: $0.225 \%, \mathrm{KCl}: 0.01 \%, \mathrm{CaCl}$ : $0.0045 \%, \mathrm{NaHCO}_{3}: 0.005 \%$ ) and aseptically isolated after germination.

\section{Pairing tests}

Intrastock pairings were made using 8-12 single spore mycelia, which were paired in all possible combinations. Inocula from each culture were placed $1 \mathrm{~cm}$ apart in petri dishes. Usually two pairings were made in an $8.5 \mathrm{~cm}$ petri dish. Paired mycelia were incubated for $4-5$ wks before examination. For interstock pairings, two different isolates per mating type were selected from each stock as testers; these were paired in all possible combinations. Additional testers were included in some interstock pairings. For interpreting the pairing tests the terminology of Chase and Ullrich (1985) is used, i.e., incompatibility (= homogenic incompatibility) and compatibility denote pairing responses controlled by mating type factors. Intersterility (heterogenic incompatibility) and interfertility imply pairing reactions regulated by factors other than mating type.

\section{DNA isolation}

DNA isolation from lyophilized mycelium (homokaryotic and heterokaryotic) was performed as described by Lee and Taylor (1990) with only slight modifications. DNA pellets were air dried and were resuspended in $100 \mathrm{fl} \mathrm{TE}$ buffer (10
mM Tris-HCl, 1 mMEDTA, pH 8.0). Concentration of DNA was examined on 1\% agarose gels (Boehringer, Mannheim). DNA was also isolated from fresh mycelium; $35-40 \mathrm{mg}$ of fresh mycelium was scraped from a petri dish and ground in liquid nitrogen. Further treatment was as described above.

Generally the DNA isolated from lyophilized mycelium was more abundant and better in quality than the DNA from fresh mycelium. The latter often was very viscous and difficult to resuspend in TE buffer, perhaps due to the presence of polysaccharides and/or carbohydrates (Bruns et al. 1990; Kim et al. 1990).

\section{PCR amplification}

DNA samples were diluted in distilled water. The PCR was used to amplify a fragment of about $1.85 \mathrm{~kb}$ homologous to a region in Saccharomyces cerevisiae rDNA from base position 34 in the 5.8S RNA to base position 1448 in 25S RNA (Hibbett \& Vilgalys 1991; Vilgalys \& Hester 1990). Primer sequences (LR7, 5.8S-R) are given by Vilgalys and Hester (1990). The PCR reactions were set up in $100 \mathrm{fl}$ volumes and were overlayed with two drops of mineral oil. Hot start PCR was applied throughout (d'Aquila et al. 1991).

Thirty cycles were performed (Biometra TRIOThermoblock), using the following parameters: $94^{\circ} \mathrm{C}$ denaturation step $\left(1^{\prime}\right), 50^{\circ} \mathrm{C}$ annealing step $\left(45^{\prime \prime}\right), 72^{\circ} \mathrm{C}$ primer extension ( $\left.2^{\prime} 45^{\prime \prime}\right)$. A final incubation step at $72^{\circ} \mathrm{C}$ (7') was added after the final cycle. Usually 3 or $5 \mathrm{fl}$ of each PCR reaction was electrophoresed on $1 \%$ agarose gels. DNA molecular weight marker VI (Boehringer, Mannheim) was used as standard.

\section{Restriction analysis of PCR products}

The amplified products were extracted with one volume of phenol:chloroform (1:1) and centrifuged at $10000 \mathrm{rpm}$ for $15 \mathrm{~min}$ (Eppendorf Centrifuge $5415 \mathrm{C}$ ). After this, $80 \mathrm{fl}$ of the aqueous portion was removed, and DNA was precipitated by addition of $8 \mathrm{fl}$ of $\mathrm{NaAc}(\mathrm{pH} 8.0)$ and 190 fl of $100 \% \mathrm{EtOH}\left(>1 \mathrm{~h},-20^{\circ} \mathrm{C}\right)$. Precipitates were collected by centrifugation (11000 rpm, $15 \mathrm{~min}$ ), washed with $750 \mathrm{fl}$ of $70 \% \mathrm{EtOH}$, air dried and resuspended in 60 fl TE buffer.

For restriction analysis, usually $10 \mathrm{fl}$ of each PCR product was digested in $20 \mathrm{fl}$ volumes. The four-base restriction enzymes Cfo I, Hae III, Hpa II, Msp I (isoschizomere of Hpa II), Nla III, and Taq I were used according to the manufacturer's instructions (New England Biolabs; Boehringer, Mannheim; Pharmacia). The restriction products were separated on $2 \%$ agarose gels. Size of the fragments was estimated by comparison with molecular weight marker VI (Boehringer, Mannheim). Results were recorded by photographing gels over a UV transilluminator. 


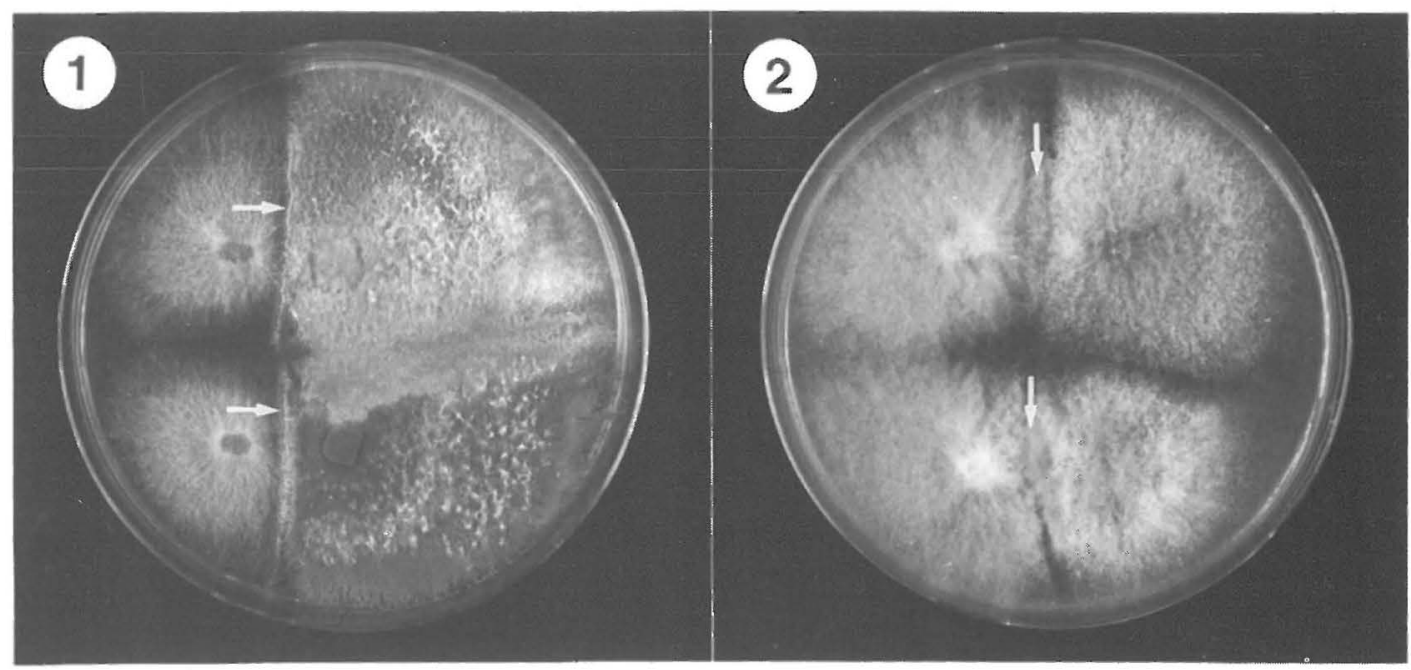

Figs. 1-2. Phellinus lundellii, stock 86-1125. - 1: Incompatible pairings of single spore isolates with a line of demarcation (arrow). - 2: Compatible pairings with a secondary mycelium forming in the contact zone (arrow).

\section{Results}

\section{Intrastock pairings (sexuality)}

All species of Phellinus are without clamp connections; moreover, homokaryons and heterokaryons cannot be distinguished by the number of nuclei per hyphal segment and thus different criteria have to be used for the interpretation of pairing reactions (Fischer \& Bresinsky 1992; Fischer 1994).

As has been shown for all other members of the $P$. igniarius group examined to date, the sexuality of $P$. laevigatus and $P$. lundellii is controlled by a unifactorial mating type system (Tables 2,3 ). The reactions observed in intrastock pairings were as follows: i) Selfing always resulted in intermingling of isolates. ii) Pairing of incompatible isolates $(\mathrm{A}=)$ resulted in the formation of a line of demarcation in the contact zone (Fig. 1). iii) Pairing of compatible isolates $(\mathrm{A}=)$ resulted in the formation of a secondary mycelium in the contact zone (Fig. 2). Generally, formation of secondary mycelium was more distinct in $P$. lundellii than in P. laevigatus. A unifactorial pattern of sexuality was also observed

Table 2. Phellinus laevigatus: Results of pairing eight single spore isolates in stock TN 3260

\begin{tabular}{|c|c|c|c|c|c|c|c|c|}
\hline single spore isolate & 1 & 2 & 3 & 4 & 5 & 6 & 7 & 8 \\
\hline 1 (A1)a & $/ \mathrm{b}$ & + & + & + & - & - & + & - \\
\hline $2(\mathrm{~A} 2$ & & 1 & - & - & + & + & - & + \\
\hline $3\left(\mathrm{~A}_{2}\right)$ & & & 1 & - & + & + & - & + \\
\hline $4\left(\mathrm{~A}_{2}\right)$ & & & & 1 & + & + & - & + \\
\hline $5\left(\mathrm{~A}_{1}\right)$ & & & & & 1 & - & + & - \\
\hline $6\left(A_{1}\right)$ & & & & & & 1 & + & - \\
\hline $7\left(\mathrm{~A}_{2}\right)$ & & & & & & & 1 & + \\
\hline $8\left(A_{1}\right)$ & & & & & & & & / \\
\hline
\end{tabular}

a mating type factor;

$\mathrm{b}$ intermingling of single spore isolates $=/$; formation of secondary mycelium $=+$; formation of a line of demarcation $=-$ 
in the newly introduced stocks from the other species.

Interstock pairings within taxa (multiple allelism)

Interstock pairings within $P$. alni (based on numerous stocks) and $P$. nigricans have been presented previously. Compatibility within the taxa was more or less complete, suggesting multiple alleles in the mating type locus (Fischer 1995).

Our three stocks of $P$. laevigatus, all from Betula but from different geographic regions, were fully compatible with each other. Six different mating type factors were assigned $\left(A_{1}-A_{6}\right)$.

Single spore isolates of only two stocks were available for $P$. lundellii; these were fully compatible, resulting in four different mating type factors $\left(\mathrm{A}_{1}-\mathrm{A}_{4}\right)$

Eighteen stocks proved to be $P$. cinereus. Except for stock 89-826, from Tilia, all were from Betula. The geographic origin was variable, including Finland, Estonia, Germany, and the United States. The pairing results between the stocks are summarized in Table 4. Compatibility between stocks was not complete, especially in pairings with 89-826 (Tilia, Estonia), TN 5745 (Betula, Finland), and 92-926b and 92-927 (Betula, USA). Here there were several pairings that were not assignable to any of the reaction types described above (Fig. 3). Leaving aside 89-826, TN 5745, 92-926b, and 92-927, altogether 25 different mating type factors were recognized $\left(\mathrm{A}_{1}-\mathrm{A}_{25}\right)$. Common mating type

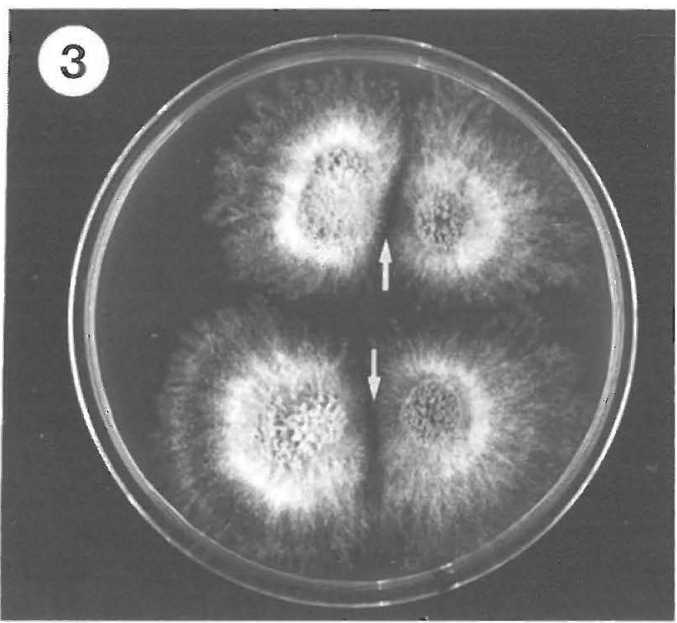

Fig. 3. Phellinus cinereus, stocks $89-826 \times 92-927$. Questionable pairings of single spore isolates; a zone free of mycelium has developed between paired isolates (arrow).

factors were found in 85-917a $\times 85-917 \mathrm{~b}, 85-$ $917 \mathrm{~b} \times 85-917 \mathrm{c}$, and 90-826a $\times 90-826 \mathrm{~b}$.

\section{Pairing tests between taxa}

Pairing results between the taxa are presented in Tables 4 and 5. P. laevigatus and P. lundellii were fully intersterile with all other taxa. Estimation of the interrelations between $P$. alni (Finland, Estonia, Germany), P. nigricans (Finland), and P. cinereus (Finland, Estonia, Germany, USA) is difficult. Intersterility

Table 3. Phellinus lundellii: Results of pairing eight single spore isolates in stock 86-1125

\begin{tabular}{ccccccccc}
\hline single spore isolate & 1 & 2 & 3 & 4 & 5 & 6 & 7 & 8 \\
\hline $1\left(\mathrm{~A}_{1}\right)^{\mathrm{a}}$ & $\mathrm{j}$ & - & + & - & + & - & + & + \\
$2\left(\mathrm{~A}_{1}\right)$ & & $/$ & + & - & + & - & + & + \\
$3\left(\mathrm{~A}_{2}\right)$ & & & $/$ & + & - & + & - & - \\
$4\left(\mathrm{~A}_{1}\right)$ & & & $/$ & + & - & + & + \\
$5\left(\mathrm{~A}_{2}\right)$ & & & & & $/$ & + & - & - \\
$6\left(\mathrm{~A}_{1}\right)$ & & & & & $/$ & + & + \\
$7\left(\mathrm{~A}_{2}\right)$ & & & & & & & \\
$8\left(\mathrm{~A}_{2}\right)$ & & & & & & & \\
\hline
\end{tabular}

\footnotetext{
a mating type factor;

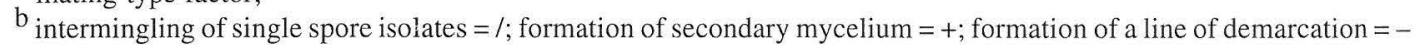


Table 4. Phellinus cinereus and P. nigricans: Interstock pairings of European and North American collections

P. cinereus $P$. nigricans

$\begin{array}{lllllllllllllllllllll}\text { Stocks } & 85- & 85- & 85- & 86- & 86- & 86- & \text { TN } & 89- & 89- & 89- & 90- & 90- & \text { TN } & \text { TN } & \text { TN } & \text { TN } & 92- & 92- & \text { TN } & \text { TN } \\ & 917 \mathrm{a} & 917 \mathrm{~b} & 917 \mathrm{c} & 9 \mathrm{a} & 9 \mathrm{~b} & 9 \mathrm{c} & 3308 & 822 \mathrm{a} & 826 & 828 \mathrm{~b} & 826 \mathrm{a} & 826 \mathrm{~b} & 5745 & 5747 & 5748 & 5759 & 926 \mathrm{~b} & 927 & 3301 & \end{array}$

4405

P. cinereus:

85-917a

$85-917 b$

$85-917 \mathrm{c}$

$86-9$ a

$86-9 b$

$86-9 \mathrm{c}$

TN 3308

89-822a

$89-826$

89-828b

90-826a

$90-826 \mathrm{~b}$

TN 5745

TN5747

TN 5748

TN 5759

92-926b

92-927

P. nigricans

TN 3301

$\begin{array}{lll}50^{\mathrm{a}} & 75+ \\ & 50 & 75\end{array}$

$\begin{array}{lll}75 & + \\ 50 & +\end{array}$

$\begin{array}{ll}+ & + \\ + & + \\ + & + \\ + & + \\ 50 & +\end{array}$

$\begin{array}{lll}+ & + & + \\ + & + & + \\ + & + & + \\ + & (+) & + \\ + & + & + \\ 50 & + & + \\ & 50 & +\end{array}$

TN 4405

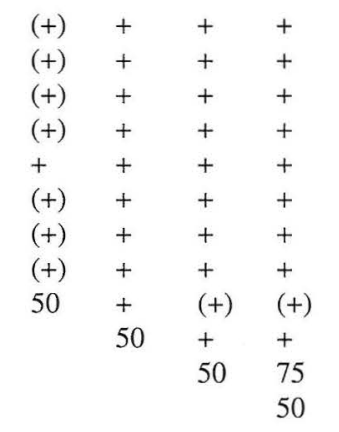$$
\begin{array}{llll}
(+) & + & + & + \\
(+) & + & + & + \\
(+) & + & + & + \\
(+) & + & + & + \\
+ & + & + & + \\
(+) & + & + & + \\
(+) & + & + & + \\
(+) & + & + & + \\
50 & + & (+) & (+) \\
& 50 & + & + \\
& & 50 & 75 \\
& & & 50
\end{array}
$$$$
\begin{array}{ll}
+ & + \\
(+) & (+) \\
+ & + \\
(+) & + \\
+ & + \\
+ & + \\
+ & + \\
+ & + \\
(+) & + \\
+ & + \\
(+) & + \\
+ & + \\
50 & +
\end{array}
$$

$+$

$+$

$\begin{array}{lll}+ & + & + \\ (+) & (+) & (+)\end{array}$

-

$-{ }^{\mathrm{a}}$ unifactorial pattern $=50$; compatibility complete $=+$; compatibility incomplete $=(+)$; one mating type factor in common $=75$; intersterility complete $=-;$ intersterility incomplete $=(-)$. 
between $P$. cinereus and $P$. alni was complete (Table 5). As was partly shown before (Fischer 1995), there are numerous positive results between $P$. alni (Finland, Estonia, Germany) and $P$. nigricans (Finland). The pairing results between $P$. cinereus and $P$. nigricans varied according to the geographic origin of the stocks (Fig. 4, Table 4): the German, Estonian, and North American stocks of $P$. cinereus were fully intersterile with $P$. nigricans, whereas the Finnish stocks of $P$. cinereus were fully compatible with $P$. nigricans except for TN 3308 $(P$. cinereus $)$, which exhibited a reduced compatibility with TN 4405 ( $P$. nigricans).

\section{PCR amplification}

PCR amplification was performed for all stocks and several single spore isolates of $P$. cinereus, $P$. alni, $P$. nigricans, and $P$. lundellii as well as for two stocks of $P$. laevigatus and the unidentified stock 76-18. Amplification products were always obtained with DNA from lyophilized mycelium; for this a DNA dilution of 1:500 in distilled water usually was successful. Amplification products were sometimes weak or absent with DNA from fresh mycelium, and in these cases an additional phenolization step was applied and/or DNA was diluted up to 1:2000. In Fig. 5 gel electrophoresis of PCR products is shown for $P$. alni, 76-18, P. nigricans, $P$. laevigatus, $P$. lundellii, and some stocks of $P$. cinereus. No length heterogeneity of the PCR product was observed and a uniform band of approximately $1.85 \mathrm{~kb}$ was consistently revealed.

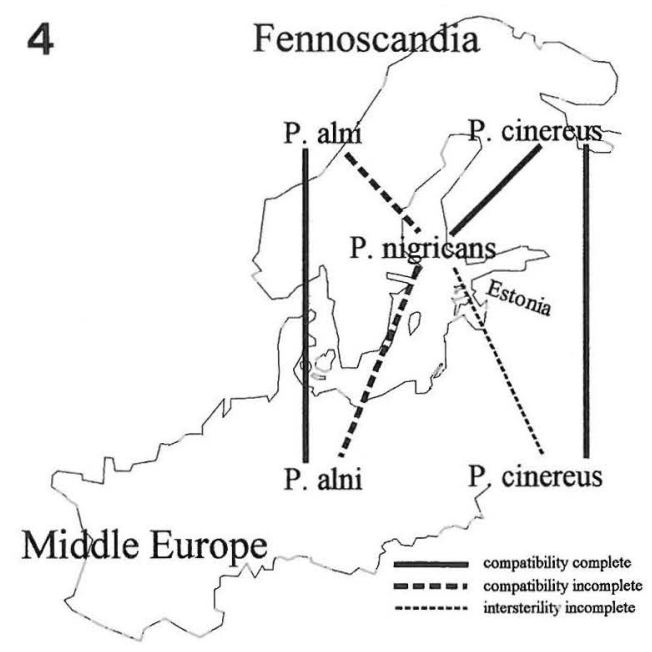

Fig. 4. Pairing relationships between Phellinus alni, $P$. nigricans, and $P$. cinereus from Central Europe, Estonia, and Fennoscandia.

This was also true for the stocks of $P$. cinereus not included in Fig. 5.

Probably due to insufficient specificity of the PCR amplification, additional bands were observed in some stocks. In 76-18 several bands appeared between approximately $350 \mathrm{bp}$ and 600 bp, and in TN 5759 ( $P$. cinereus) one additional band was detected at approximately $510 \mathrm{bp}$ (Fig. 5). The latter also appeared in some other stocks of $\mathrm{P}$. cinereus. Usually a reduction of the primer concentration improved the specificity of the reaction. No PCR products were obtained in the controls.

Table 5. Phellinus on Betula and P. alni: Pairings of European and North American collections

\begin{tabular}{|c|c|c|c|c|c|c|c|}
\hline & I & II & III & IV & V & VI & VII \\
\hline P. $\operatorname{alni}(\mathrm{I})$ & $+^{\mathrm{a}}$ & $(+)$ & - & - & - & - & - \\
\hline P. nigricans (II) & & + & $(-)$ & - & - & - & - \\
\hline $\begin{array}{l}\text { P. cinereus (III) } \\
\text { (Central Europe, Estonia) }\end{array}$ & & & $(+)$ & $(+)$ & $(+)$ & - & - \\
\hline $\begin{array}{l}P . \text { cinereus }(\mathrm{IV}) \\
\text { (Fennoscandia) }\end{array}$ & & & & + & $(+)$ & - & - \\
\hline $\begin{array}{l}P . \text { cinereus (V) } \\
\text { (USA, Michigan) }\end{array}$ & & & & & + & - & - \\
\hline P. laevigatus (VI) & & & & & & + & - \\
\hline P. lundellii (VII) & & & & & & & + \\
\hline
\end{tabular}

a compatibility complete $=+;$ compatibility incomplete $=(+)$; intersterility complete $=-;$ intersterility incomplete $=(-)$ 


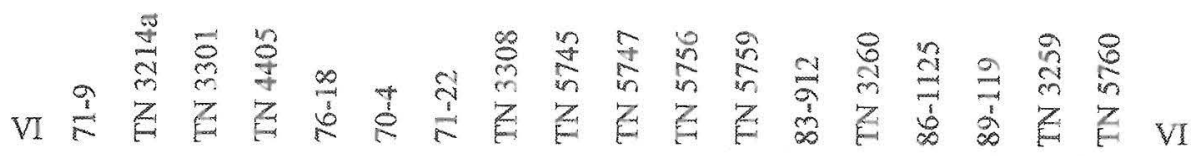

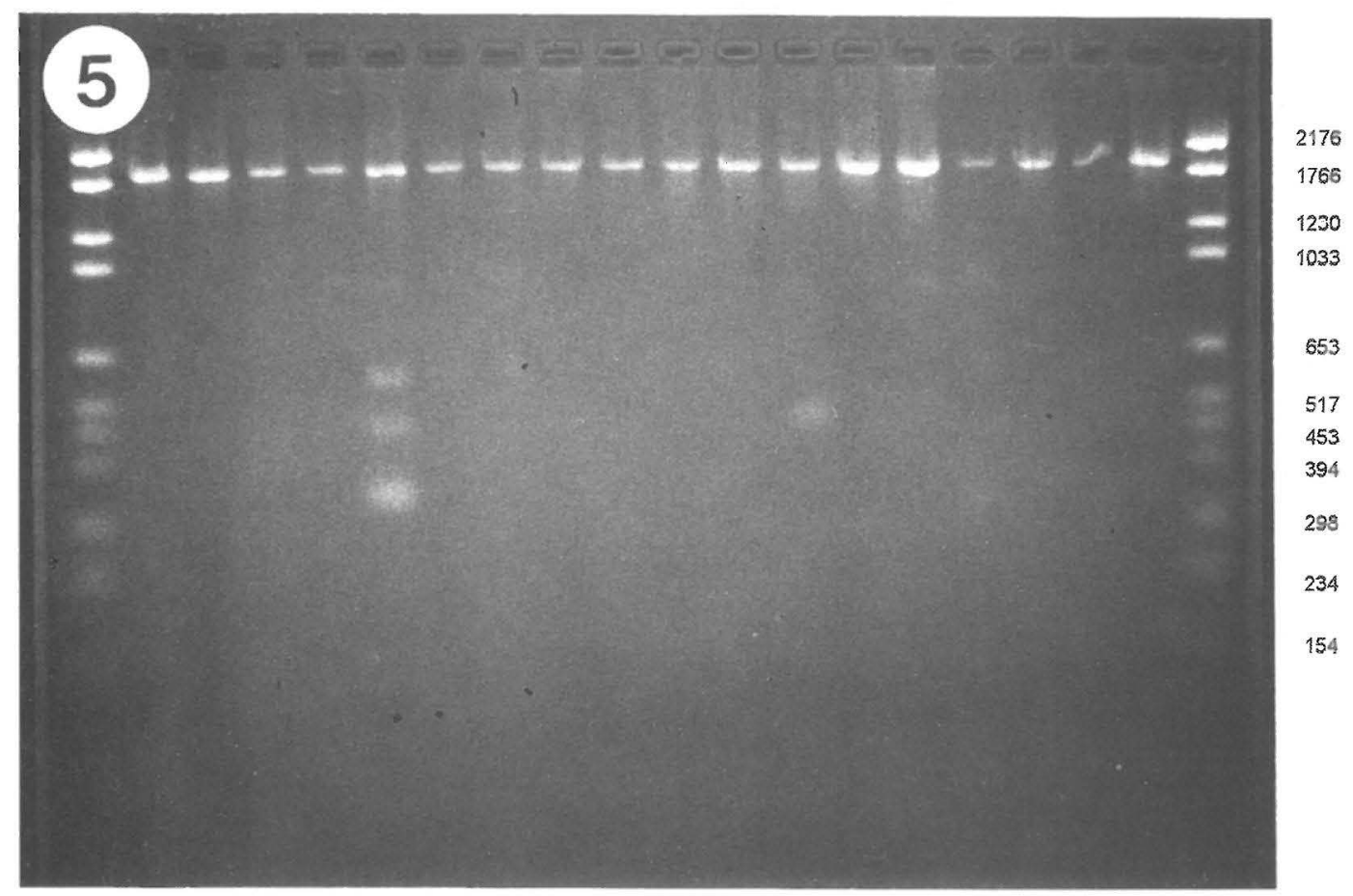

Fig. 5. Gel electrophoresis of PCR products of rDNA on $1 \%$ agarose. Estimated size of fragment is $1.85 \mathrm{~kb}$. VI = molecular weight standard; fragment sizes in base pairs. 71-9, TN 3214a (Phellinus alni); TN 3301, TN 4405 ( $P$. nigricans); 7618 (unidentified); 70-4, 71-22, TN 3308, TN 5745, TN 5747, TN 5756, TN 5759 ( $P$. cinereus); 83-912, TN $3260(P$. laevigatus); 86-1125, 89-119, TN 3259, TN 5760 (P. lundellii).

\section{RFLP analysis of PCR products}

Within stocks no divergence was observed between homokaryons and heterokaryons (data not shown).

The possible existence of intraspecific variation was examined in more detail in $P$. cinereus. The 18 stocks available were digested with Cfo I, Hae III, Hpa II (Msp I), Nla III, and Taq I. The RFLP phenotypes for Nla III and Taq I are presented in Figs. 6 and 7, respectively, and were identical for all stocks. This was also true for the other enzymes (data not shown). The sum of fragment sizes always corresponded well with the size of the undigested PCR product.

The following stocks were used for interspecific comparison: 71-9, TN 3214a (P. alni); 76-18 (unidentified); TN 3301, TN 4405 ( $P$. nigricans); 70-4, 71-22, TN 3308, TN 5745, TN 5747, TN 5756, TN 5759 ( $P$. cinereus); 83-912, TN $3260(P$. laevigatus); 86-1125, 89-119, TN 3259, TN 5760 ( $P$. lundellii). The enzymes used were as given above. The RFLP phenotypes for Cfo I, Hpa II, and

Figs. 6-7. Restriction fragments. VI = molecular weight standard; fragment sizes in base pairs. 71-9, TN 3214a (Phellinus alni); 76-18 (unidentified); TN 3301, TN 4405 (P. nigricans); 70-4, 71-22, TN 3308, TN 5745, TN 5747, TN 5756, TN 5759 (P. cinereus); 83-912, TN 3260 ( $P$. laevigatus); 86- 1125, 89-119, TN 3259, TN 5760 ( $P$. lundellii). - 6: Nla III restriction fragments electrophoresed on $2 \%$ agarose. - 7: Taq I restriction fragments electrophoresed on $2 \%$ agarose. 


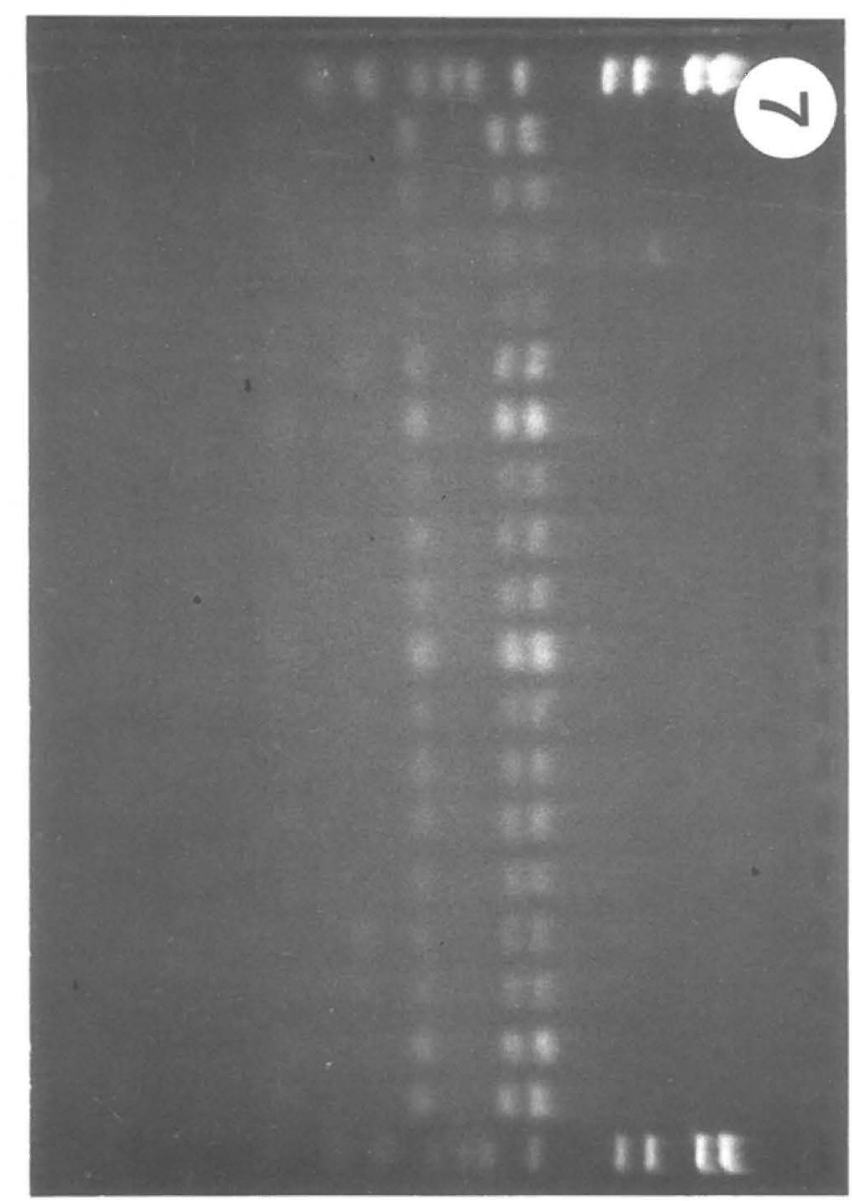

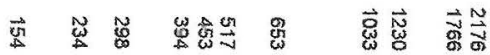

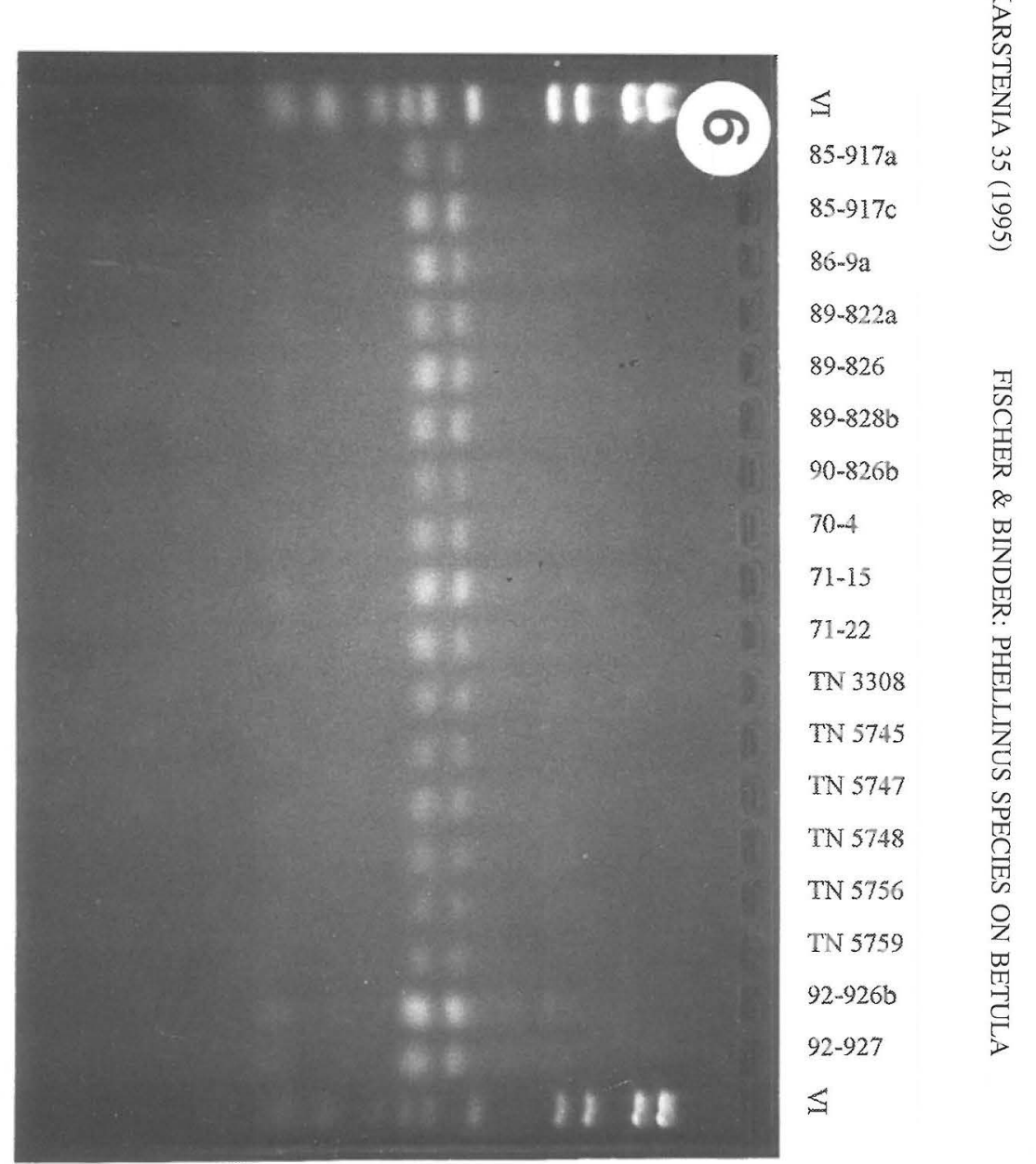

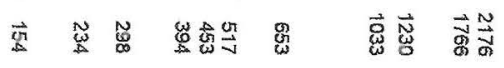


Table 6. Distribution of restriction gragments.

Stocks

\begin{tabular}{|c|c|c|c|c|c|c|c|c|c|c|c|c|c|c|c|c|c|c|c|c|}
\hline Enzyme & No. & Size ${ }^{a}$ & $\frac{a}{i}$ & $\begin{array}{l}\frac{\mathscr{g}}{\tilde{J}} \\
z \\
z\end{array}$ & $\frac{\infty}{b}$ & $\begin{array}{l}\bar{D} \\
\underset{m}{Z} \\
Z\end{array}$ & $\begin{array}{l}\cong \\
\stackrel{o}{7} \\
z \\
z\end{array}$ & $\stackrel{T}{~}$ & $\underset{\dddot{T}}{\stackrel{7}{7}}$ & $\begin{array}{l}\stackrel{\infty}{\circ} \\
\stackrel{n}{Z} \\
z\end{array}$ & $\begin{array}{l}\stackrel{n}{\mathbb{Z}} \\
\text { z } \\
z\end{array}$ & $\begin{array}{l}\text { 焉 } \\
\text { Z }\end{array}$ & $\begin{array}{l}\stackrel{\circ}{n} \\
\tilde{n} \\
z\end{array}$ & $\begin{array}{l}\text { n } \\
\text { n } \\
z\end{array}$ & $\frac{7}{a}$ & $\begin{array}{l}\stackrel{8}{0} \\
\text { I } \\
\text { Z } \\
\text { Z }\end{array}$ & $\stackrel{\cong}{\beth}$ & $\stackrel{a}{\equiv}$ & $\begin{array}{l}\text { जे } \\
\text { ż } \\
\text { Z }\end{array}$ & $\begin{array}{l}8 \\
\delta \\
z \\
z\end{array}$ \\
\hline \multirow[t]{8}{*}{ Cfo I } & 1 & 760 & 0 & 0 & 0 & 0 & 0 & 0 & 0 & 0 & 0 & 0 & 0 & 0 & 0 & 0 & 1 & 1 & 1 & 1 \\
\hline & 2 & 630 & 1 & 1 & 1 & 1 & 1 & 1 & 1 & 1 & 1 & 1 & 1 & 1 & 1 & 1 & 1 & 1 & l & 1 \\
\hline & 3 & 620 & 1 & 1 & 1 & 1 & 1 & 0 & 0 & 0 & 0 & 0 & 0 & 0 & 1 & 1 & 0 & 0 & 0 & 0 \\
\hline & 4 & 320 & 0 & 0 & 0 & 0 & 0 & I & 1 & I & 1 & 1 & 1 & 1 & 0 & 0 & 0 & 0 & 0 & 0 \\
\hline & 5 & 320 & 0 & 0 & 0 & 0 & 0 & 1 & 1 & 1 & 1 & 1 & 1 & 1 & 0 & 0 & 0 & 0 & 0 & 0 \\
\hline & 6 & 210 & 1 & 1 & 1 & 1 & 1 & 1 & 1 & 1 & 1 & 1 & 1 & 1 & 1 & 1 & 1 & 1 & 1 & 1 \\
\hline & 7 & 170 & 1 & 1 & 1 & 1 & 1 & 1 & 1 & 1 & 1 & 1 & 1 & 1 & 1 & 1 & 0 & 0 & 0 & 0 \\
\hline & 8 & 140 & 1 & 1 & 1 & 1 & 1 & 1 & 1 & 1 & 1 & 1 & 1 & 1 & 1 & 1 & 1 & 1 & 1 & 1 \\
\hline \multirow[t]{10}{*}{ Hae III } & 1 & 850 & 0 & 0 & 0 & 0 & 0 & 0 & 0 & 0 & 0 & 0 & 0 & 0 & 0 & 0 & 1 & 1 & 1 & 1 \\
\hline & 2 & 650 & 1 & 1 & 1 & 1 & 1 & 1 & 1 & 1 & 1 & 1 & 1 & 1 & 0 & 0 & 0 & 0 & 0 & 0 \\
\hline & 3 & 630 & 0 & 0 & 0 & 0 & 0 & 0 & 0 & 0 & 0 & 0 & 0 & 0 & 1 & 1 & 0 & 0 & 0 & 0 \\
\hline & 4 & 440 & 0 & 0 & 0 & 0 & 0 & 0 & 0 & 0 & 0 & 0 & 0 & 0 & 0 & 0 & 1 & 1 & 1 & 1 \\
\hline & 5 & 260 & 1 & 1 & 1 & 1 & 1 & 1 & 1 & 1 & 1 & 1 & 1 & 1 & 1 & 1 & $0^{*}$ & $0^{*}$ & $0^{*}$ & $0^{*}$ \\
\hline & 6 & 260 & 1 & 1 & 1 & 1 & 1 & 1 & 1 & 1 & 1 & 1 & 1 & 1 & $1^{*}$ & $1^{*}$ & 1 & 1 & 1 & 1 \\
\hline & 7 & 180 & 1 & 1 & 1 & I & 1 & 1 & 1 & 1 & 1 & 1 & 1 & 1 & 1 & 1 & 1 & 1 & 1 & 1 \\
\hline & 8 & 180 & 1 & 1 & 1 & 1 & 1 & 1 & 1 & 1 & 1 & 1 & 1 & 1 & 1 & 1 & 0 & 0 & 0 & 0 \\
\hline & 9 & 150 & 1 & 1 & 1 & 1 & 1 & 1 & 1 & 1 & 1 & 1 & 1 & 1 & 1 & 1 & 0 & 0 & 0 & 0 \\
\hline & 10 & 130 & 1 & 1 & 1 & 1 & 1 & 1 & 1 & 1 & 1 & 1 & 1 & 1 & $1^{*}$ & $1^{*}$ & $1^{*}$ & $1^{*}$ & $1^{*}$ & $1^{*}$ \\
\hline \multirow[t]{8}{*}{ Hpa II } & 1 & 900 & 0 & 0 & 0 & 0 & 0 & 1 & 1 & 1 & 1 & 1 & 1 & 1 & 0 & 0 & 1 & 1 & 1 & 1 \\
\hline & 2 & 880 & 0 & 0 & 0 & 0 & 0 & 0 & 0 & 0 & 0 & 0 & 0 & 0 & 1 & 1 & 0 & 0 & 0 & 0 \\
\hline & 3 & 700 & 1 & 1 & 1 & 1 & 1 & 0 & 0 & 0 & 0 & 0 & 0 & 0 & 0 & 0 & 0 & 0 & 0 & 0 \\
\hline & 4 & 430 & 1 & 1 & 1 & 1 & 1 & 1 & 1 & 1 & 1 & 1 & 1 & 1 & 1 & I & 1 & 1 & 1 & 1 \\
\hline & 5 & 280 & 1 & 1 & 1 & 1 & 1 & 1 & 1 & 1 & 1 & 1 & 1 & 1 & 1 & 1 & I & 1 & 1 & 1 \\
\hline & 6 & 280 & 0 & 0 & 0 & 0 & 0 & 0 & 0 & 0 & 0 & 0 & 0 & 0 & 0 & 0 & 0 & 0 & 0 & 0 \\
\hline & 7 & 180 & 1 & 1 & 1 & 1 & 1 & 1 & 1 & 1 & 1 & 1 & 1 & 1 & 1 & 1 & 1 & 1 & 1 & 1 \\
\hline & 8 & 180 & 1 & 1 & 1 & 1 & 1 & 0 & 0 & 0 & 0 & 0 & 0 & 0 & 0 & 0 & 0 & 0 & 0 & 0 \\
\hline \multirow[t]{8}{*}{ Nla III } & 1 & 610 & 1 & 1 & 1 & 1 & I & 1 & 1 & 1 & 1 & 1 & I & 1 & 1 & 1 & 1 & 1 & 1 & 1 \\
\hline & 2 & 500 & 1 & 1 & 1 & 1 & 1 & 1 & 1 & 1 & 1 & 1 & 1 & 1 & 1 & I & 0 & 0 & 0 & 0 \\
\hline & 3 & 470 & 1 & 1 & 1 & 1 & 1 & 1 & 1 & 1 & 1 & 1 & 1 & 1 & 0 & 0 & 0 & 0 & 0 & 0 \\
\hline & 4 & 460 & 0 & 0 & 0 & 0 & 0 & 0 & 0 & 0 & 0 & 0 & 0 & 0 & 0 & 0 & I & 1 & 1 & 1 \\
\hline & 5 & 450 & 0 & 0 & 0 & 0 & 0 & 0 & 0 & 0 & 0 & 0 & 0 & 0 & 1 & 1 & 0 & 0 & 0 & 0 \\
\hline & 6 & 370 & 0 & 0 & 0 & 0 & 0 & 0 & 0 & 0 & 0 & 0 & 0 & 0 & 0 & 0 & 1 & 1 & 1 & 1 \\
\hline & 7 & 220 & 1 & 1 & 1 & 1 & 1 & 1 & 1 & 1 & 1 & 1 & 1 & 1 & 1 & 1 & 1 & 1 & 1 & 1 \\
\hline & 8 & 130 & 0 & 0 & 0 & 0 & 0 & 0 & 0 & 0 & 0 & 0 & 0 & 0 & 0 & 0 & 1 & 1 & 1 & 1 \\
\hline \multirow[t]{6}{*}{ Taq I } & 1 & 650 & 1 & 1 & 1 & 1 & 1 & 1 & 1 & 1 & 1 & 1 & 1 & 1 & 1 & 1 & 1 & 1 & 1 & 1 \\
\hline & 2 & 570 & 1 & 1 & 1 & 1 & 1 & 1 & 1 & 1 & 1 & 1 & 1 & 1 & 0 & 0 & 1 & 1 & 1 & 1 \\
\hline & 3 & 530 & 0 & 0 & 0 & 0 & 0 & 0 & 0 & 0 & 0 & 0 & 0 & 0 & 1 & 1 & 0 & 0 & 0 & 0 \\
\hline & 4 & 360 & 1 & 1 & 1 & 1 & 1 & 1 & 1 & 1 & 1 & 1 & 1 & 1 & 1 & 1 & 1 & 1 & 1 & 1 \\
\hline & 5 & 170 & 1 & 1 & 1 & 1 & 1 & 1 & 1 & 1 & 1 & 1 & 1 & 1 & 1 & 1 & 1 & 1 & 1 & 1 \\
\hline & 6 & 130 & 1 & 1 & 1 & 1 & 1 & 1 & 1 & 1 & 1 & 1 & 1 & 1 & 1 & 1 & 1 & 1 & 1 & 1 \\
\hline
\end{tabular}

a Fragment sizes estimated by comparison with molecular weight standard;

b stocks tested: 71-9; TN 3214a (Phellinus alni); 76-18 (unidentified); TN 3301, TN 4405 (P. nigricans); 70-4, 71-22, TN 3308, TN 5745, TN 5747, TN 5756, TN 5759 (P. cinereus); 83-912, TN 3260 (P. laevigatus); 86-1125, 89-119, TN 3259, TN 5760 (P. lundellii);

* fragments questionable.

Figs. 8-9. Restriction fragments. VI = molecular weight standard; fragment sizes in base pairs. 71-9, TN 3214a (Phellinus alni); 76-18 (unidentified); TN 3301, TN 4405 (P. nigricans); 70-4, 71-22, TN 3308, TN 5745, TN 5747, TN 5756, TN 5759 (P. cinereus); 83-912, TN 3260 (P. laevigatus); 86 - 1125, 89-119, TN 3259, TN 5760 ( $P$. lundellii). - 8: Cfo I restriction fragments electrophoresed on $2 \%$ agarose. - -9 : Hpa II restriction fragments electrophoresed on $2 \%$ agarose. 


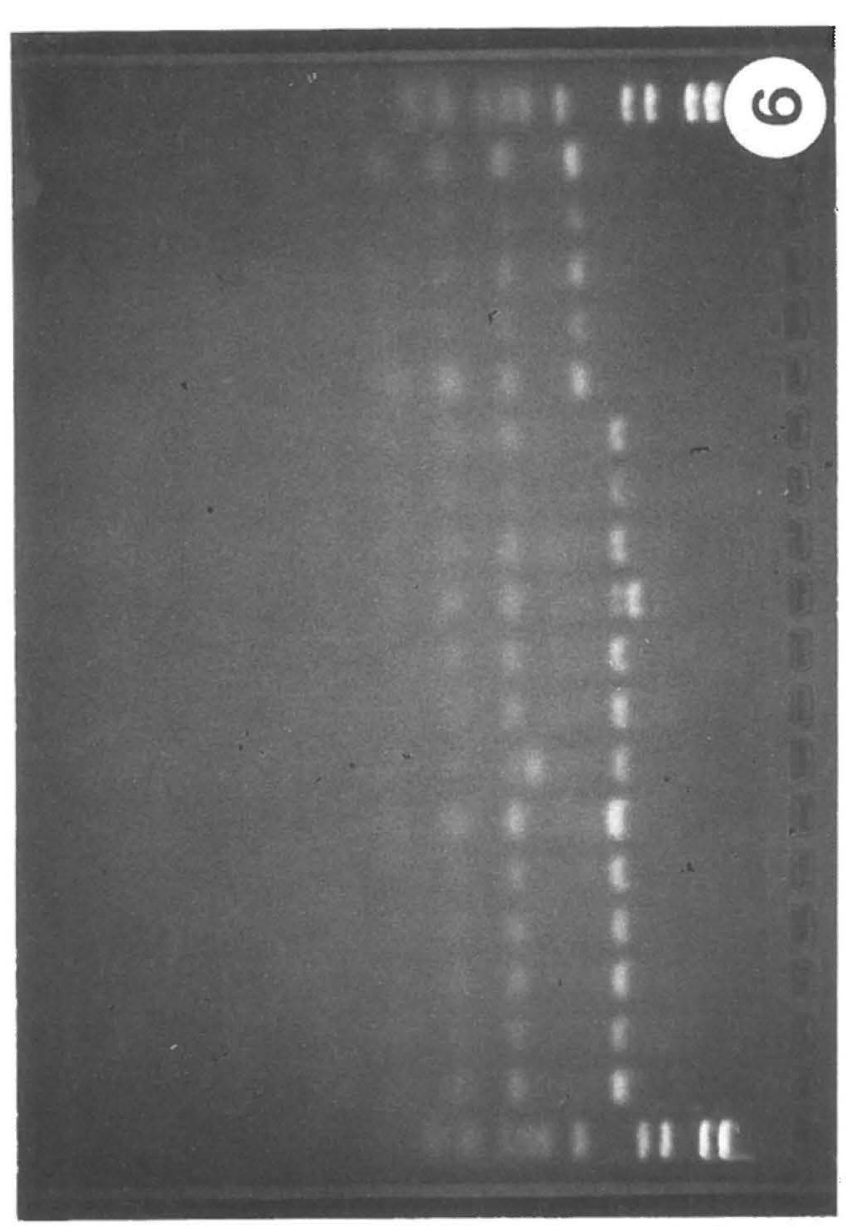

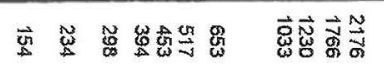

71-9

TN 3214a

76-18

TN 3301

TN 4405

$70-\frac{4}{4}$

71-22

TN 3308

TN 5745

TN 5747

TN 5756

TN 5759

83-912

TN 3260

86-1125

$89-119$

TN 3259

TN 5760

$\leqq$

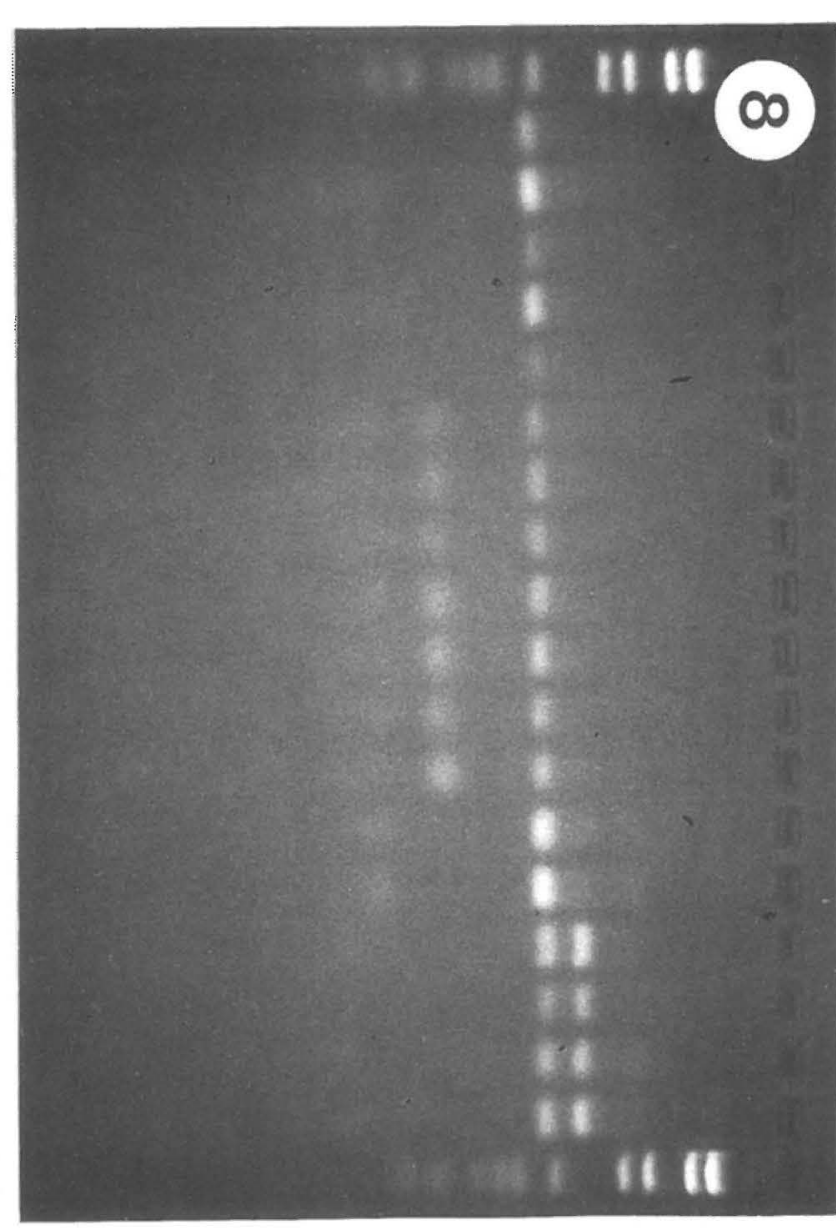

$\leqq$

$71-9$

TN $3214 a$

$76-18$

TN 3301

TN 4405

$70-4$

71-22

TN 3308

TN 5745

TN 5747

TN 5756

TN 5759

83-912

$\mathrm{TN} 3260$

86-1125

89-119

TN 3259

TN 5760

$\leq$

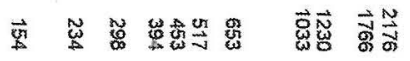




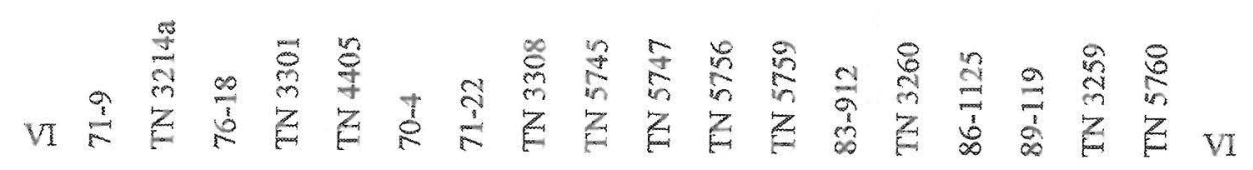

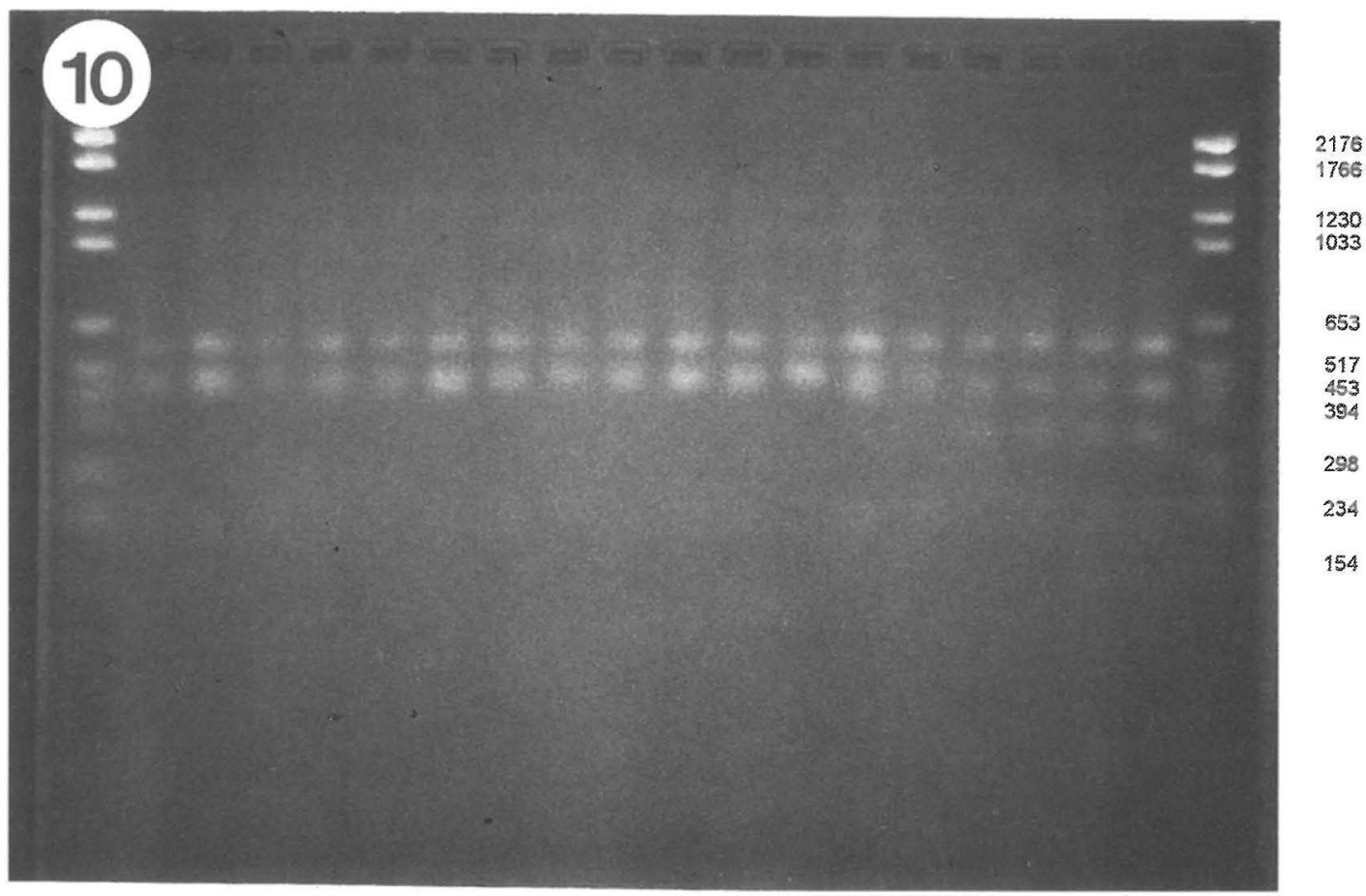

Fig. 10. Nla III restriction fragments electrophoresed on $2 \%$ agarose. VI = molecular weight standard; fragment sizes in base pairs. 71-9, TN 3214a (Phellinus alni); 76-18 (unidentified); TN 3301, TN 4405 ( $P$. nigricans); 70-4, 71-22, TN 3308, TN 5745, TN 5747, TN 5756, TN 5759 ( $P$. cinereus); 83-912, TN 3260 (P. laevigatus); 86-1125, 89-119, TN 3259, TN 5760 (P. lundellii).

Nla III are shown in Figs. 8, 9, and 10. Altogether 40 unique bands were resolved among the 18 stocks in five taxa (Table 6). Three restriction phenotypes were detected for Cfo I, Hae III, Hpa II, and Nla III, and two for Taq I. No single enzyme allowed the identification of all taxa. When the results for all enzymes were pooled, except for $P$. nigricans all taxa could be unequivocally assigned to one unique rDNA type (Table 6). The RFLP data of $P$. nigricans and 76-18 were identical with $P$. alni. Different taxa partly exhibited common restriction phenotypes. For Cfo I, $P$. alni and $P$. laevigatus were identical; for Hpa II, $P$. cinereus and $P$. lundellii were identical; for Hae III and Nla III, $P$. alni and $P$. cinereus were identical; and for Taq I, $P$. alni, $P$. cinereus, and $P$. lundellii were identical.
Only $P$. cinereus and P.laevigatus, and $P$. laevigatus and $P$. lundellii were different for each enzyme. As is shown in detail for $P$. cinereus (Figs. $6,7)$, no intraspecific variation was observed for any of the taxa (Table 6).

There was good agreement between size estimates for the undigested PCR products and the sums of fragment sizes. Except for Nla III and Taq I the estimate of the fragment size sum was sometimes hindered by the presence of double bands. In addition, identification of small restriction fragments was questionable for Cfo I and Hae III. After application of running parameters especially suitable for resolution of double bands and/or small fragments, some fragments still remained questionable; these are indicated by an asterisk in Table 6 . 
Partial digestion was only rarely observed. The irregular band of about $510 \mathrm{bp}$, noted for Hpa II (and its isoschizomere, Msp I) in TN 5759 (Fig. 9), probably corresponds to the secondary band observed in the PCR amplification (Fig. 5). This band was not obtained in digestions with the other enzymes. For Hpa II (and Msp I), another product of partial digestion of approximately $1000 \mathrm{bp}$ appeared in TN 5745. The origin of this fragment is unknown.

\section{Discussion}

\section{Pairing tests}

A unifactorial pattern of sexuality seems common for all members of the $P$. igniarius group; the mating type factor, $\mathrm{A}$, throughout proves to be multiallelic (multiple allelism, $A_{1}-A_{n}$ ). The results of pairing tests can therefore be used to assign specimens to specific taxa. In this study four taxa were shown to occur on Betula: P. nigricans, $P$. cinereus, $P$. laevigatus, and $P$. lundellii. Except for $P$. cinereus, within these taxa all the interstock pairings were fully compatible (Tables 4,5 ). Negative reactions in $P$. cinereus were partly due to homogenic incompatibility (common mating type factors, Fig. 1; see Raper 1966), and probably partly due to heterogenic incompatibility (functioning epistatically to the mating type compatibility system; see Chase \& Ullrich 1985, 1990a,b; Wells \& Wong 1989; Fischer \& Bresinsky 1992). Common mating type factors were observed only in stocks of the same geographic origin, for example in 85-917a, 85-917b, and 85-917c, all collected in a bog within the Bayerischer Wald National Park, Germany.

The reasons for the questionable reactions (Fig. 3 ) in $P$. cinereus remain uncertain. Such reactions have been noted also in other species of Phellinus (Fischer 1994, 1995); assignment as positive or negative is not possible with the data at hand. Appearance of this reaction type is similar to the socalled barrage, indicating a common B-factor in the bifactorial genus Pleurotus (Fr.) Kumm. (Hilber 1982; Bresinsky et al. 1987). Questionable reactions were mainly observed in pairings with 89-826 (Tilia, Estonia), TN 5745, and TN 5759 (Betula, Finland) and 92-926b and 92-927 (Betula, USA). The differences in the collections from Estonia and North America may indicate an early stage of speciation, caused by different hosts or geographic isolation.
$P$. nigricans seems to serve as a linkage between $P$. alni and $P$. cinereus in Fennoscandia, where, to a different extent, it is positive with both taxa (Fig. 4). Otherwise, when paired with collections from Central and Eastern Europe, Fennoscandian $P$. nigricans is mostly compatible with $P$. alni (from different substrata, not including Betula), but with one exception intersterile with $P$. cinereus (Fischer, 1995). It is also intersterile with $P$. cinereus from the United States.

This shows that speciation between $P$. alni, $P$. nigricans, and $P$. cinereus is not yet complete in Fennoscandia, where via positive pairings of $P$. nigricans with both $P$. cinereus and $P$. aln $i$ a gene flow between these otherwise intersterile taxa is possible. Including Estonia and Central Europe, a process of even wider scale can be seen: via positive pairings between Central European $P$. alni and Fennoscandian $P$. alni and/or $P$. nigricans, genetic information can reach Fennoscandia, and hence be transferred to $P$. cinereus. Since no mating barriers exist between $P$. cinereus from Fennoscandia and Central Europe, genetic information from Central European $P$. alni may finally pass to Central European $P$. cinereus.

Nothing is known about the vitality of secondary mycelia established in vivo between different taxa - for example, P. alni $\times$ P. nigricans; it very well might be reduced as compared to intraspecific secondary mycelia. Distribution of species of Phellinus occurs by airborne spores; since the prevailing winds are to the west in Central Europe, the establishment of propagules between Central European and Fennoscandian stocks may in any case be exceptional.

Central European findings of $P$. nigricans would have been most helpful in addressing this set of problems, but they were not available to us. As shown for Fennoscandian $P$. nigricans, also in Armillaria (Fr.:Fr.) Staude one taxon is positive with two other, intersterile, taxa; however, the compatible taxa are geographically isolated in Armillaria, originating from Europe and North America (Anderson et al. 1980).

\section{PCR and RFLP}

The chosen rDNA region, containing both highly conserved and more variable sequences, has been repeatedly used as an aid in molecular taxonomy of closely related fungal species (Hibbett \& 
Vilgalys 1991; Chen \& Hoy 1993; Fischer 1995). Gel electrophoresis of undigested PCR products consistently revealed a uniform band of approximately $1.85 \mathrm{~kb}$ in $P$. alni, $P$. nigricans, $P$. cinereus, $P$. laevigatus, and $P$. lundellii.

Four RFLP phenotypes were observed, one each for $P$. cinereus, $P$. laevigatus, and $P$. lundellii and one in common for $P$. alni and $P$. nigricans. There was no full agreement between pairing test data and RFLP data. P. nigricans and $P$. cinereus are compatible in Fennoscandia, but exhibit different RFLP phenotypes for Cfo I and Hpa II. Which type of fragment pattern is to be expected in secondary mycelia resulting from compatible pairings between isolates with different RFLP phenotypes? Apparently secondary mycelia are heterokaryotic, containing nuclei of both the paired homokaryons (Fischer 1987; Fischer \& Bresinsky 1992). Thus, in positive pairings between $P$. nigricans and $P$. cinereus, nuclei representing both RFLP types should be recovered in the secondary mycelium. As a means of characterizing the particular rDNAs, isolation and subculturing of interspecific secondary mycelia is currently under way.

The RFLP phenotype of the unidentified stock $76-18$ was identical with $P$. alni and $P$. nigricans; because of lack of single spore mycelia the final assignment of 76-18 to one of these taxa is not possible. Within the area under study, $P$. alni apparently does not occur on Betula; that $76-18$ represents $P$. nigricans seems more likely therefore.

\section{Conclusions}

The occurrence of four and possibly even more species of Phellinus on a single host genus is unusual. $P$. laevigatus and $P$. lundellii are almost exclusively, and $P$. nigricans and $P$. cinereus mainly found on dead trees (Jahn 1963, 1967; Niemelä 1972, 1975, pers. comm.; Domanski 1972; Domanski et al. 1973; Plank 1978; Niemelä \& Kotiranta 1982; Breitenbach \& Kränzlin 1986; Parmasto 1993, pers. comm.). Speciation in parasitic species of Phellinus often is correlated with host preferences. This probably is due to varying rates of basidiospore germination on different substrata in vivo. Amazingly, at least in vitro, basidiospores of extremely specialized taxa are able to germinate on numerous substrata other than the actual host, as has been demonstrated for Piptoporus betulinus (Paine 1968; Paine \& Merrill 1971) or Fomitopsis cajanderi (P.Karsten) Kotl. \& Pouz. (Tsuneda \& Kennedy 1980). Similar observations have been made for parasitic species of the $P$. igniarius group, although results are preliminary (Fischer 1987). In saprophytic taxa, as are those on Betula, fungus-host relationships seem less important. Even so, the taxa treated here only rarely share the same tree, possibly due to somewhat divergent habitat preferences, i.e., humidity or decay grade of the wood. Both $P$. nigricans and $P$. cinereus mostly occur on still standing but dead trees; however, P. cinereus also is found as a saproparasite on damaged, but still living trees. P. laevigatus and $P$. lundellii both grow on fallen, dead trunks; in rare cases, they are found side by side (Niemelä, pers. comm.).

$P$. nigricans apparently is a rare species. With the data at hand, it has been demonstrated only for Fennoscandia. An unequivocal identification of $P$. nigricans is not possible without pairing tests and RFLP data. To date no reliable species delimitation between $P$. nigricans, $P$. alni, and $P$. cinereus is possible with use of traditional characters. At least, the specific status of $P$. nigricans is somewhat less uncertain now than just recently (Fischer 1995), thanks to the unique pairing behaviour demonstrated for $P$. alni and $P$. cinereus.

$P$. cinereus has a wide distribution. It is the first species of the $P$. igniarius group shown by pairing tests and RFLP data to exist in North America. Most findings from Betula that are designated as $P$. igniarius, $P$. alni, or $P$. nigricans probably refer to $P$. cinereus. There is some evidence that the species also occurs in East Asia (preliminary results).

Acknowledgements. Special thanks go to Drs. Tuomo Niemelä and Erast Parmasto for providing specimens and helpful discussion. We also would like to thank Drs. Andreas Bresinsky and Norbert Luschka for providing specimens. Karin Schadendorf is thanked for technical assistance. This manuscript was improved by the suggestions of two anonymous reviewers.

\section{References}

Adams, D.H. \& Roth, L.F. 1967: Demarcation lines in paired cultures of Fomes cajanderi as a basis for detecting genetically distinct mycelia. - Canad. J. Bot. 45:1583-1589. 
Anderson, J.B., Korhonen, K. \& Ullrich, R.C. 1980: Relationships between European and North American biological species of Armillaria mellea. Exp. Mycol. 4:87-95.

Benkert, D. 1977: Die Porlinge und Schichtpilze der Potsdamer Umgebung. - Gleditschia 5:165-202.

Bondartsev, A.S. 1912: Griby, sobrannye na stvolakh lesnykh porod y Bryanskom opytnom lesnichestve. - Trudy Lesn. Opytn. Delu Rossii 37:1-56.

Bondartsev, A.S. 1971: The Polyporaceae of the European USSR and Caucasia. — 896 pp. Israel Progr. Sci. Transl., Jerusalem.

Bourdot, H. \& Galzin, A. 1927: Hymnomyctes de France. - 761 pp. Paul Lechevalier, Paris.

Breitenbach, J. \& Kränzlin, F. 1986: Pilze der Schweiz 2. Nichtbltterpilze (Heterobasidiomycetes, Aphyllophorales, Gastromycetes). - $416 \mathrm{pp}$. Mykologia, Luzern.

Bresinsky, A., Fischer, M., Meixner, B. \& Paulus, W. 1987: Speciation in Pleurotus. - Mycologia 79:234 245.

Bruns, T.D., Fogel, R. \& Taylor, J.W. 1990: Amplification and sequencing of DNA from fungal herbarium specimens. - Mycologia 82:175-184.

Chase, T.E. \& Ullrich, R.C. 1985: Genetics of intersterility in Heterobasidion annosum. - Mycol. Soc. Amer. Newslett. 36(1): 20.(Abstract)

Chase, T.E. \& Ullrich, R.C. 1990a: Genetic basis of biological species in Heterobasidion annosum: Mendelian determinants. - Mycologia 82:67-72.

Chase, T.E. \& Ullrich, R.C. 1990b: Five genes determining intersterility in Heterobasidion annosum. Mycologia 82:73-81.

Chen, W. \& Hoy, J.W. 1993: Molecular and morphological comparison of Pythium arrhenomanes and P. graminicola. - Mycol. Res. 97:1371-1378.

D'Aquila, R.T., Bechtel, L.J., Videler, J.A., Eron, J.E., Gorczyca, P. \& Kaplan, J.C. 1991: Maximizing sensitivity and specificity of PCR by preamplification heating. - Nucleic Acids Res. 19:3749.

Domanski, S. 1972: Fungi. Polyporaceae I, Mucronoporaceae I. - 235 pp. Foreign Sci. Publ. Dept., Warsaw.

Domanski, S., Orlos, H. \& Skirgiello, A. 1973: Fungi. Polyporaceae II (pileatae), Mucronoporaceae II (pileatae), Ganodermataceae, Bondarzewiaceae, Boletopsidaceae, Fistulinaceae. - 332 pp. Foreign Sci. Publ. Dept., Warsaw.

Donk, M.A. 1971: Notes on European polypores. IX. On some species of Hymenochaetaceae. - Proc. Koninkl. Nederlandse Akad. Wetensch. C. 74:405421.

Donk, M.A. 1974: Check list of European polypores. — 469 pp. North-Holland Publ. Co., Amsterdam \& London.

Eriksson, J. 1958: Studies in the Heterobasidiomycetes and Homobasidiomycetes - Aphyllophorales of Muddus National Park in North Sweden. - Symb. Bot. Upsalienses 16:1-172.

Erkkilä, R. \& Niemelä, T. 1986: Polypores in the parks and forests of the City of Helsinki. - Karstenia 26:1-40.

Fischer, M. 1987: Biosystematische Untersuchungen an den Porlingsgattungen Phellinus Qul. und Inonotus Karst.
- Biblioth. Mycol. 107:1-133.

Fischer, M. 1994: Pairing tests in the Phellinus pini group. - Mycologia 86:524-539.

Fischer, M. 1995: Phellinus igniarius and its closest relatives in Europe. - Mycol. Res. 99.

Fischer, M. \& Bresinsky, A. 1992: Phellinus torulosus: sexuality and evidence of intersterility groups. Mycologia 84:823-833.

Hibbett, D.S. \& Vilgalys, R. 1991: Evolutionary relationships of Lentinus to the Polyporaceae: Evidence from restriction analysis of enzymatically amplified ribosomal DNA. - Mycologia 83:425439.

Hilber, O. 1982: Die Gattung Pleurotus (Fr.) Kummer unter besonderer Bercksichtigung des Pleurotus eryngiiFormenkomplexes. - Biblioth.Mycol. 87:1-448.

Jahn, H. 1962: Der Espen-Feuerschwamm (Phellinus tremulae), ein gefrchteter Feind der Espe. Westflische Pilzbriefe 3:94-102.

Jahn, H. 1963: Mitteleuropische Porlinge (Polyporaceae s. 1.) und ihr Vorkommen in Westfalen (unter Ausschlua der resupinaten Arten). - Westflische Pilzbriefe 4:1-143.

Jahn, H. 1967: Die resupinaten Phellinus-Arten in Mitteleuropa. - Westflische Pilzbriefe 6:37-108.

Jahn, H. 1977: Phellinus lundellii und sein Vorkommen in Deutschland (BRD). - Westflische Pilzbriefe 11:59-66.

Jahn, H. 1979: Pilze die an Holz wachsen. - 268 pp. Busse, Herford.

Jahn, H. \& Jahn, M.A. 1986: Konstanz und Fluktuation der Pilzvegetation in Norra Warleda (Uppland). Beobachtungen auf einem schwedischen Bauernhof. - Westflische Pilzbriefe 10-11:352-378.

Jülich, W. 1984: Die Nichtbltterpilze, Gallertpilze und Bauchpilze. - 626 pp. G. Fischer, Stuttgart \& New York.

Kim, W.K., Mauthe, W., Hausner, G. \& Klasen, G.R. 1990: Isolation of high molecular weight DNA and double-stranded RNAs from fungi. — Canad. J. Bot. 68:1898-1902.

Kotlaba, F. 1984: Zemepisn rozsireni a ekologie chorosu (Polyporales s. 1.) v Ceskoslovensku. — 194 pp., 123 maps. Academia, Praha.

Kreisel, H. 1961: Die phytopathogenen Großpilze Deutschlands. - 284 pp. G. Fischer, Jena.

Kreisel, H. 1987: Pilzflora der Deutschen Demokratischen Republik. - 281 pp. G. Fischer, Jena.

Lee, S.B. \& Taylor, J.W. 1990: Isolation of DNA from fungal mycelia and single cells. Pp. 282-287. - In: Innis, M.A., Gelfand, D.H., Sninsky, J.J. \& White, T.J. (eds.), PCR protocols, a guide to methods and applications. - Academic Press, San Diego.

Luschka, N. 1994: Die Pilze des Nationalparks Bayerischer Wald. - Hoppea 53:1-374.

Niemelä, T. 1972: On Fennoscandian polypores II. Phellinus laevigatus (Fr.) Bourd. \& Galz. and P. lundellii Niemelä, n. sp. - Ann. Bot. Fennici 9:41-59.

Niemelä, T. 1974: On Fennoscandian polypores III. Phellinus tremulae (Bond.) Bond. et Borisov. - Ann. Bot. Fennici 11:202-215.

Niemelä, T. 1975: On Fennoscandian polypores IV. 
Phellinus igniarius, P. nigricans and P. populicola, $n$. sp. - Ann. Bot. Fennici 12:93-122.

Niemelä, T. 1977: The effects of temperature on two culture types of Phellinus tremulae (Fungi, Hymenochaetaceae). - Ann. Bot. Fennici 14:21-24.

Niemelä, T. \& Kotiranta, H. 1982: Polypore survey of Finland 2. The genus Phellinus. — Karstenia 22:2742.

Paine, R.L. 1968: Germination of Polyporus betulinus basidiospores on non-host species. Phytopathology 58:1062.

Paine, R.L. \& Merrill, W. 1971: Host specificity of Polyporus betulinus. — Phytopathology 61:905.

Parmasto, E. 1976: Studies on Yakutian fungi II. - Eesti NSV Tead. Akad. Toimed. Biol. 25:316-321.

Parmasto, E. 1985: The species concept in Hymenochaetaceae (Fungi, Hymenomycetes). Proc. Indian Acad. Sci. 94:369-380.

Parmasto, E. 1993: Distribution maps of Estonian fungi 1: 1-34. Inst. Zool. Bot., Tartu.

Plank, S. 1978: kologie und Verbreitung holzabbauender Pilze im Burgenland. - Wissensch. Arb. Burgenland
61:1-207.

Raper, J.R. 1966: Genetics of sexuality in higher fungi. 283 pp. Ronald Press, New York.

Renvall, P., Renvall, T. \& Niemelä, T. 1991: Basidiomycetes at the timberline in Lapland 2. An annotated checklist of the polypores of northeastern Finland. - Karstenia 31:13-28.

Tsuneda, J. \& Kennedy, L.L. 1980: Basidiospore germination and substrate preference in Fomes fomentarius and Fomitopsis cajanderi. - Mycologia 72:204-208.

Vilgalys, R. \& Hester, M. 1990: Rapid genetic identification and mapping of enzymatically amplified ribosomal DNA from several Cryptococcus species. - J. Bacteriol. 172:4238-4246.

Wells, K. \& Wong, G. 1989: Partial intersterility and evidence of allopatric speciation in Exidiopsis plumbescens (Exidiaceae). - Mycologia 81:567586.

Received 19 September 1994 